\title{
Iptek bagi Masyarakat Produsen Tempurung Kelapa Desa Murangan
}

\author{
Windha Mega P. D. ${ }^{1}$, M. Rizkillah ${ }^{2}$ Irton $^{3}$ \\ 1,2,3 Universitas AMIKOM Yogyakarta, Jl. Ringroad Utara Yogyakarta \\ ${ }^{1}$ windha.m@amikom.ac.id, ${ }^{2}$ ryzkillah@gmail.com, ${ }^{3}$ distroanakmuslim@gmail.com
}

\begin{abstract}
Charcoal coconut briquete factories in DIY are potentiamarket for coconut charcoal production. Briquete coconut charcoal made by grinding coconut charcoal then prrssed and dried. One of coconut charcoal maker is Mr Agus Winarno. Coconut charcoal making process make smoke polution. The solutions is making smoke into liquid smoke to generate income and reduce envoiriment protest. In production Mr Agus cooperate with Mr Slamet Raharjo as coconut shell suplier. The main problems to collect coconut shell is high interval coconut price that incluence coconut shell price. The outputs from this activity are $2 e$ commerce web site for sale and promotions. The other outcome is make a tool to convert smoke into liquid smoke as aditional product. Business growth measure by assets growth, income and increase of profit. The methode activities are analize selling process, business management and sales" pelatihan", financial managements and website operational. The general results can improve micro enterprise income. Special outcome can enlarge sale range using IT benefits.
\end{abstract}

Keywords: e-commerce, coconut, briket, liquid smoke, coconut charcoal

\begin{abstract}
ABSTRAK
Briket tempurung kelapa wilayah DIY merupakan pangsa pasar potensial bagi perajin arang tempurung kelapa. Briket diperoleh dengan menggiling arang tempurung kelapa kemudian dicetak dan dikeringkan. Salah satu produsen arang yang menjadi mitra adalah Bapak Agus Winarno. Dalam memproduksi arang muncul kendala utama berupa polusi asap hasil pembakaran. Kedala tersebut dapat diatasi dengan menangkap polusi asap diubah menjadi asap cair sehingga meningkatkan pendapatan serta dapat menghilangkan protes warga sekitar karena polusi asap di udara. Demi kelancaran suplay tempurung Bapak Agus bekerja sama dengan bapak Slamet Raharjo sebagai pengepul tempurung. Kendala utama yang dialami dalam pengadaan tempurung adalah fluktuasi harga tempurung di pasaran dikarenakan mahalnya kelapa butir. Luaran dari kegiatan ini diantaranya membangun 2 website e-commerce untuk media promosi dan pemasaran produk untuk kedua mitra. Luaran lainnya adalah membuatkan 1 alat produksi asap cair sebagai pengolah limbah yang dijadikan produk tambahan. Sehingga perkembangan usaha yang diukur dari jumlah aset, omset dan pendapatan meningkat. Adapun metode yang dilaksanakan adalah menganalisis metode pemasaran yang berjalan, mengadakan pelatihan manajemen bisnis dan pemasaran, manajemen keuangan dan operasional website. Hasil akhir dari kegiatan ini secara umum dapat meningkatkan pertumbuhan ekonomi Usaha mikro. Dan secara khusus dapat meningkatkan ruang lingkup pemasaran dengan penggunaan teknologi informasi dalam pemasaran.
\end{abstract}

Kata kunci: e-commerce, kelapa, briket, arang tempurung, asap cair

\section{PENDAHULUAN}

Di desa Murangan, terdapat tanah kas desa yang dikelola oleh Bapak Agus Winarno untuk memproduksi arang dari bahan baku tempurung kelapa. Dalam memproduksi arang tempurung kelapa menggunakan dua buah tungku yang terbuat dari tanah liat dan bata merah yang memiliki kapasitas masing-masing tungku $700 \mathrm{~kg}$ tempurung kelapa sekali proses. Untuk mengurangi dampak pencemaran udara pada lingkungan, di sekitar tungku produksi arang sudah dilengkapi dengan kondensor sederhana berbahan aluminium, yang berfungsi merubah limbah asap menjadi asap cair. Asap cair hasil produksi memiliki banyak sekali manfaat untuk pertanian, peternakan , farmasi dll. Dikarenakan kurangnya akses pemasaran yang dimiliki, untuk saat ini hasil asap yang tertampung masih belum dijual dan dimanfaatkan. Sulitnya memasarkan asap cair dikarenakan kurangnya pengetahuan masyarakat akan manfaat yang dimiliki. Sebagai sumber pemasukan utama saat ini bapak Agus hanya mengandalkan penjualan produk utama yang berupa arang tempurung. 
Sampai saat ini pengelolaan produksi ditangani dan diawasi secara langsung oleh Bapak Agus. Dari segi manajeman keuangan juga belum dikelola secara baik. Seluruh kegiatan operasional belum dicatat dalam pembukuan sehingga sulit menentukan kemajuan dari usaha yang dijalani.

Dalam memenuhi kebutuhan bahan bakunya, Pak Agus bekerja sama dengan suplier tempurung kelapa, yaitu bapak Slamet Raharjo. Kendala utama yang dihadapi adalah fluktuasi harga tempurung di lapangan. Jika harga beli tempurung mengalami kenaikan dari Rp1.000 menjadi Rp1.200/kg maka kiriman tempurung akan terhenti. Harga tersebut adalah harga pokok pembelian batok, belum ditambah biaya operasional Rp200/kg. Dengan rincian dipergunakan untuk biaya bahan bakar kendaraan angkut berikut dengan tenaga bongkar muat. Terdapat pengepul tempurung lain di wilayah sekitar Sleman. Sama halnya dengan Bapak Agus, dalam pengelolaan keuangan dan pemasarannya, Pak Slamet belum melakukan pembukuan dan masih tercampur dengan keuangan pribadinya.

Berdasarkan permasalahan di atas, solusi pengenalan dan pemasaran produk asap cair ke masyarakat yang lebih luas dapat dilakukan dengan media online yaitu pembuatan e-commerce. Limbah asap dapat diubah menjadi asap cair dengan membuat 1 unit alat penangkap asap baru dari bahan stainless steel, sehingga produk yang dihasilkan memiliki kualitas lebih baik dan memiliki pasar yang luas. Pengelolaan keuangan masih belum maksimal sehingga pengembangan usaha belum bagus. Disolusi dengan melakukan pelatihan manajemen pemasaran dan pengelolaan keungan agar perkembangan usaha menjadi lebih baik.

\section{METODE PELAKSANAAN}

Berdasarkan permasalahan dan target luaran pada kegiatan pengabdian IbM ini, berikut metode pelaksanaan kegiatannya:

\subsection{Metode persiapan}

Kegiatan ini diawali dengan melakukan kesepakatan dengan kedua mitra, yaitu UD Agus sebagai produsen arang tempurung kelapa dan suplier tempurung kelapa di desa Moyudan, Sleman, Yogyakarta. Dengan melakukan proses wawancara dan observasi, maka diperoleh kesepakatan rencana solusi yang akan diselesaikan melalui kegiatan ini. Adapun solusi yang telah disepakati adalah sebagai berikut: 1) Agar pemilik dapat memasarkan produknya (arang dan asap cair) ke wilayah yang lebih luas, maka diadakan pelatihan manajemen pemasaran, serta pembuatan website e-commerce sebagai media promosi arang tempurung kelapa dan asap cair. 2) Agar pemilik usaha mampu mengelola website e-commerce, maka diadakan Pelatihan wawasan pemasaran dan teknologi yang meliputi materi: Pelatihan Komputer Dasar, Editing foto, serta Pelatihan Pengelolaan dan Penggunaan Sistem Informasi sehingga mitra dapat mengembangkan pemasarannya mandiri. 3) Tempurung yang diproduksi dengan menggunakan tungku yang berada di dalam tanah memiliki kualitas yang bagus karena lebih kering dan matang. Dari segi efisiensi tenaga operasional juga lebih efisien karena tidak perlu ditunggu secara terus menerus. Untuk menanggulangi polusi asap yang dihasilkan dipergunakan pipa stainless steel berukuran $15 \times 15 \mathrm{~cm}$ sebanyak 4 buah dengan panjang total 24 meter sebagai penangkap asap cair. Dengan mengubah sudut kemiringan pipa diperoleh asap cair dengan kualitas lebih baik dari segi warna dan aroma. Warna menjadi lebih gelap dan aroma menyengat sebagai syarat utama bahan baku fungisida organik. 4) Pelatihan manajemen keuangan memberi pemahaman manajemen pembukuan yang baik agar mitra mampu mengelola keuangan usahanya dengan baik. Dapat memisahkan dengan keuangan pribadi.

\subsection{Pelaksanaan}

Pelaksanaan kegiatan pengabdian ini diawali dengan pelatihan untuk membuka wawasan mitra tentang pentingnya pengelolaan bisnis, seperti pemasaran, produksi dan keuangan.

Agar mitra dapat pemasarkan produknya ke wilayah yang lebih luas, maka disediakan website $e$ commerce. Selanjutnya diadakan pelatihan pengelolaan website dengan materi sebagai berikut: 1) Pelatihan editing Foto dasar. 2) Pembuatan email dan media sosial lain seperti facebook, instagram. 3) Pengelolaan website masing-masing seperti upload foto produk, artikel, pengelolaan transaksi pemesanan dan konfirmasi pesanan serta cetak nota pemesanan. 
Untuk pengelolaan produksi, limbah asap yang dihasilkan dari proses pembakaran arang tempurung kelapa dapat dikelola sehingga menjadi produk lain yang mempunyai nilai jual, yaitu asap cair. Yaitu dengan membuat 1 unit alat penangkap asap baru dari bahan stainless steel sebagai pipa pendingin, serta memperbaiki tungku pemanas, agar tidak bocor. Sehingga dengan alat ini, mitra mempunyai produk baru yang dapat dipasarkan dan hasilnya melebihi produk utamanya.

Selanjutnya dalam pengelolaan keuangan, diadakan pendampingan pengelolaan keuangan, dengan materi sebagai berikut: 1) Mengumpulkan semua bukti-bukti transaksi. 2) Memasukkan transaksi ke buku jurnal dan buku besar. 3) Membuat neraca saldo. 4) Membuat laporan keuangan seperti laporan laba rugi, laporan perubahan modal, dan neraca. 5) Pencatatan jurnal dilakukan tiap hari, dan pemindahan ke buku besar, neraca saldo dan laporan keuangan dapat dibuat setiap akhir bulan.

\subsection{Pemantauan}

Kegiatan pemantauan dilakukan oleh anggota dosen pengabdi untuk memastikan apakah tujuan dari kegiatan pengabdian ini berhasil terwujud, serta mengetahui apakah masih terdapat kendala dalam pengelolaan website, alat maupun aktivitas pencatatan keuangan. Pemantauan dilakukan dengan komunikasi lewat whatsapp dan kunjungan langsung ke mitra 1 bulan setelah kegiatan pengabdian ini selesai. Hal-hal yang dipantau meliputi aktivitas upload konten website, pengelolaan transaksi penjualan melalui website, kinerja alat produksi asap cair, serta pengelolaan keuangan seperti pencatatan setiap aktivitas usaha pada jurnal, pembuatan laporan dan kondisi keuangan mitra.

\section{HASIL DAN PEMBAHASAN}

Mengacu pada rencana kegiatan telah dilaksanakan dengan berbagai capaian yang sudah dilakukan diantaranya sesuai dengan target yang dicapai sebagai berikut:

1. Untuk membangun website e-commerce sebagai media promosi arang tempurung kelapa dan asap cair, maka perlu dilakukan tahapan perancangan sistem. Di definisikan beberapa aktor yang berperan dalam aplikasi, seperti ditunjukkan pada Gambar 1 di bawah ini:

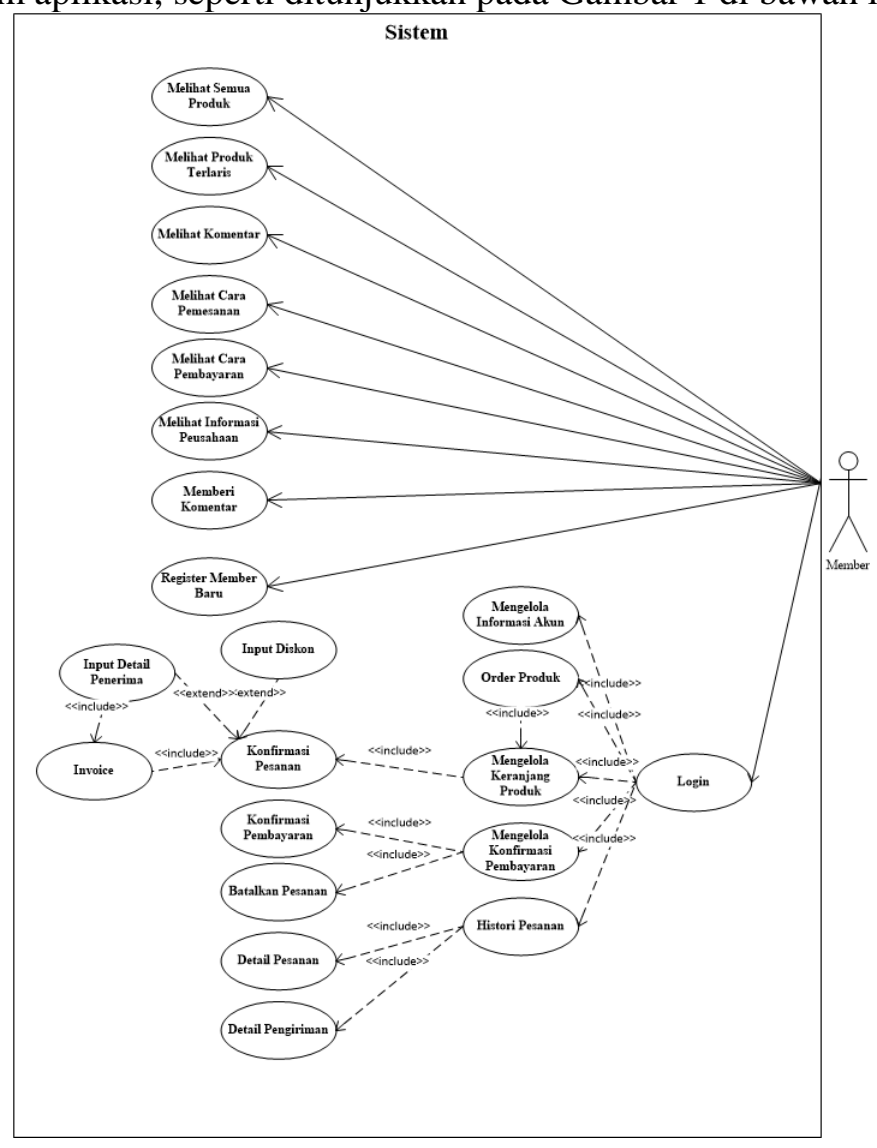

Gambar 1. Usecase Diagram Admin 
untuk lebih detailnya berikut adalah aktor-aktor yang akan berperan, a) Pengelola (admin), diberikan hak akses penuh untuk mengelola seluruh perilaku yang ada dalam pengaturan website. b) Pelanggan, diberikan hak akses untuk dapat mengorder produk, membatalkan pesanan maupun melihat pesanan yang sudah dipesan.

Selain perancangan sistem, dilakukan juga tahapan perancangan basis data menggunakan ERD, yang digunakan untuk menjelaskan hubungan antar data dan memodelkan struktur data dalam basis data berdasarkan objek-objek dasar data yang mempunyai hubungan antar relasi. Berdasarkan rancangan ERD, maka diperoleh relasi tabel pada basis data $e$ commerce yang akan dibangun, seperti ditunjukkan pada Gambar 2 di bawah ini:

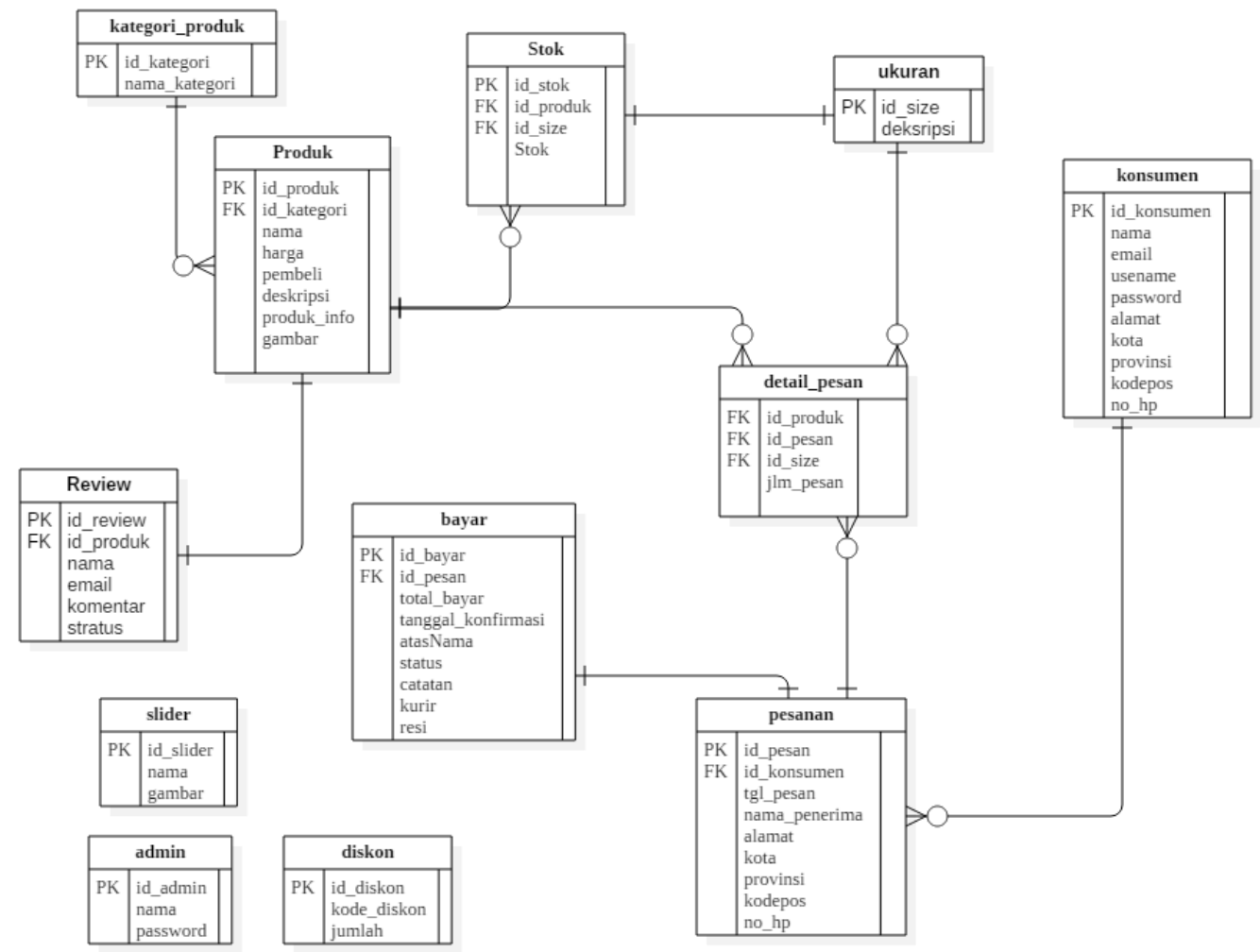

Gambar 2. Relasi Antar Tabel

Dari hasil perancangan di atas, maka kegiatan selanjutnya adalah implementasi sistem, meliputi implementasi database menggunakan MySQL, implementasi website menggunakan bahasa pemrograman PHP Framework Code Igniter, Webserver menggunakan XAMPP. Gambar 3 Berikut tampilan website keranjang belanja user: 

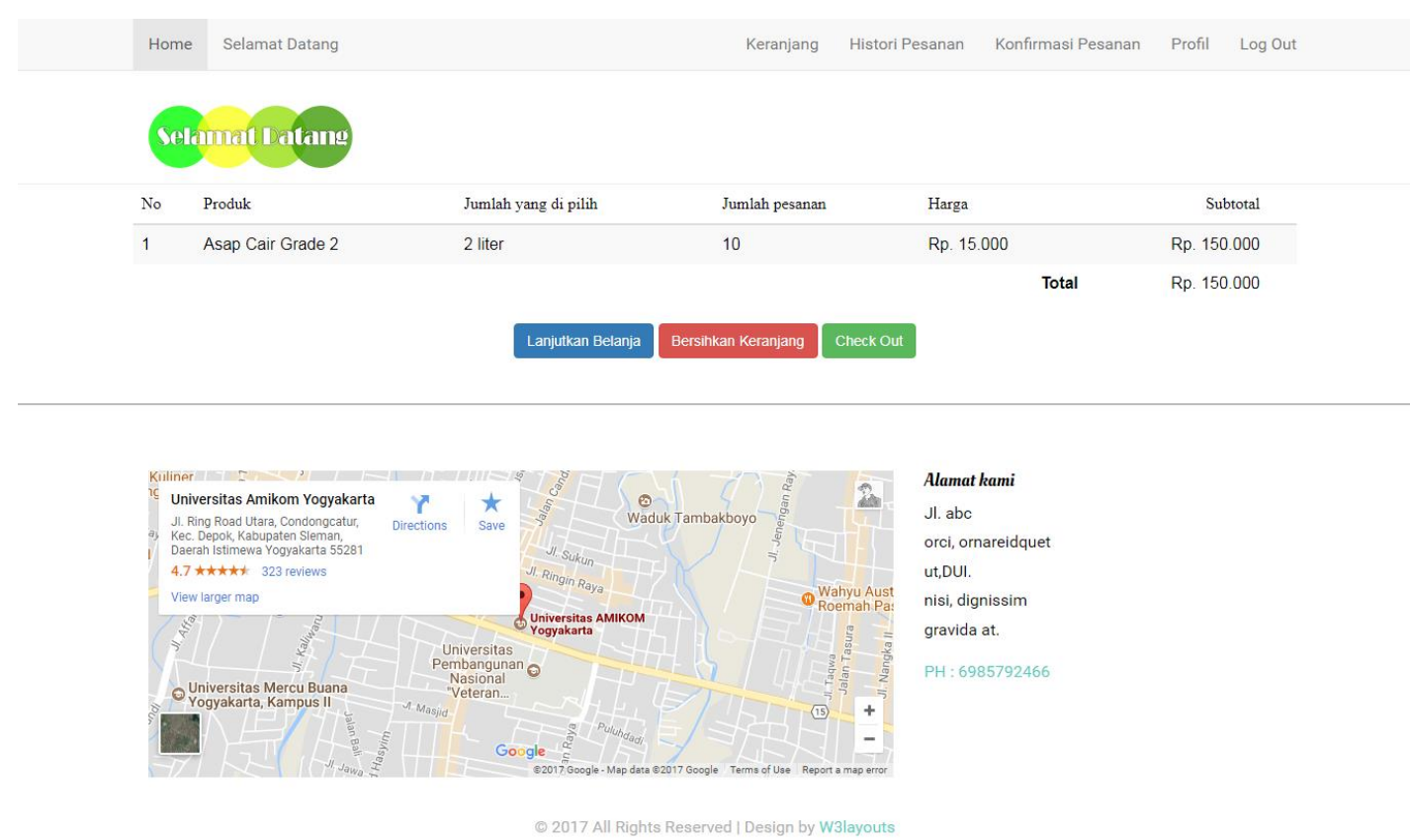

Gambar 3. Tampilan keranjang belanja

Pada website ini, juga dapat digunakan untuk mencetak beberapa laporan, seperti laporan pesanan tiap periode, invoice pesanan, laporan stok barang, seperti ditunjukkan pada Gambar 4 di bawah ini:

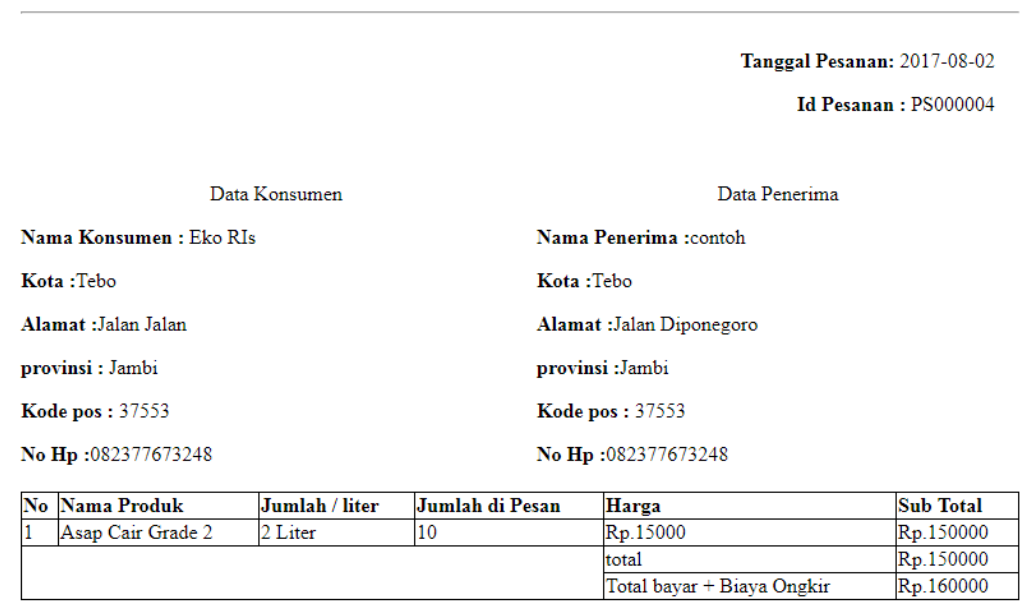

Gambar 4. Tampilan laporan pemesanan

Dengan dibuatnya website e-commerce, maka daerah pemasaran arang dan asap cair pada mitra semakin luas. Memperkenalkan produk arang dari tempurung kelapa dan asap cair ke masyarakat luas. Termasuk di dalamnya disertai artikel yang dapat memberikan informasi yang detail tentang produk yang dihasilkan serta kegunaannya sebagai salah satu sarana untuk mengedukasi pasar. Termasuk mempermudah pembeli untuk melakukan pemesanan walaupun dari jauh.

2. Agar mitra dapat melakukan pengelolaan website secara mandiri, seperti melakukan perannya sebagai Admin website, maka diberikan peralatan penunjang pengelolaan website penjualan serta pelatihan manajemen website seperti update produk, upload gambar, editing foto, upload artikel, serta melakukan konfirmasi terhadap pesanan. 


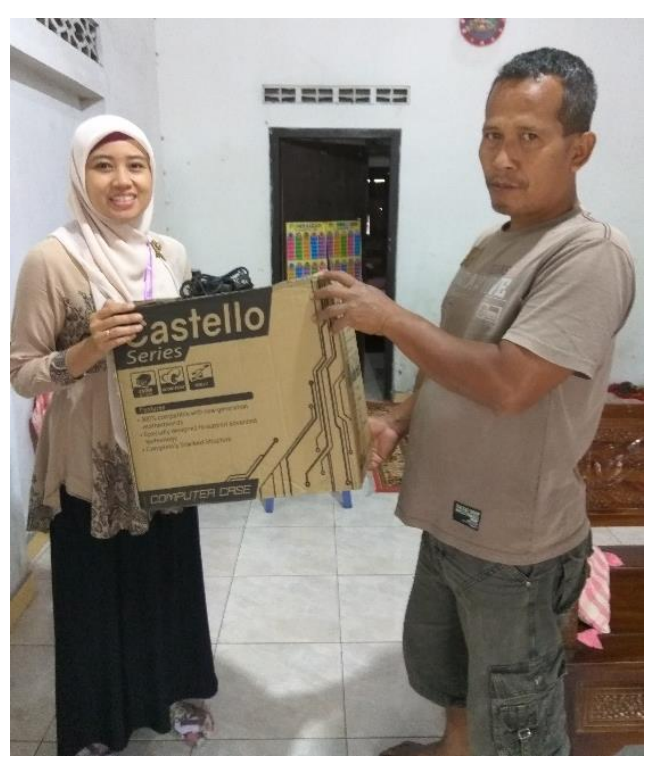

Gambar 5. Penyerahan peralatan penunjang pengelolaan E-Commerce

3. Untuk mengatasi permasalahan polusi asap yang dihasilkan karena produksi arang tempurung dengan pembakaran tempurung kelapa, maka perlu dibuat alat untuk mengubah limbah asap menjadi asap cair yang mempunyai nilai jual. Sehingga mitra mempunyai tambahan produk yang dapat dijual. Dengan mengganti pipa pendingin alumunium dengan ketebalan 0,3 $\mathrm{mm}$ panjang 24 meter menjadi stainless steel ketebalan $1.5 \mathrm{~mm}$ panjang $24 \mathrm{~m}$. Seperti Gambar 6 di bawah ini:

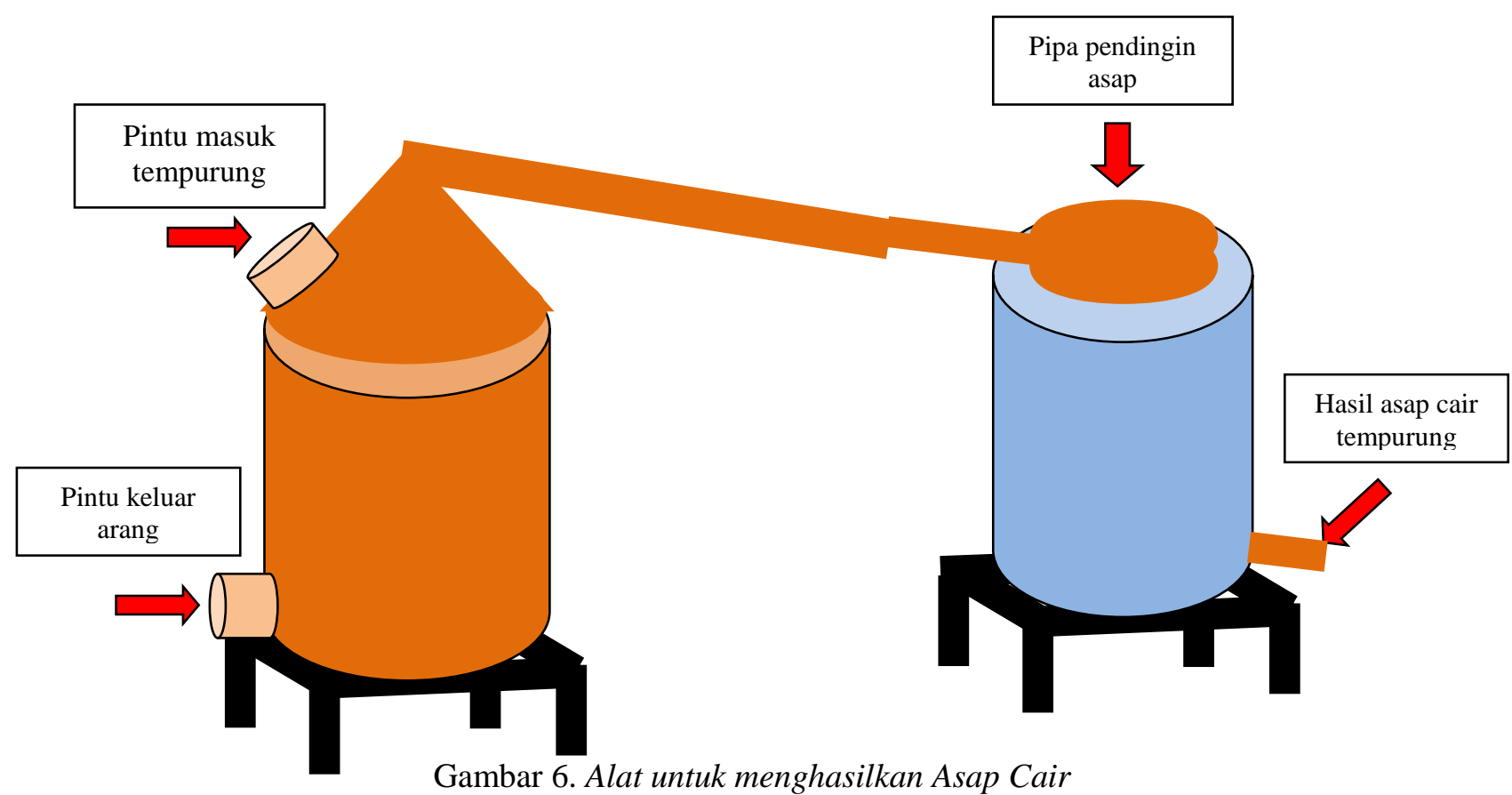

Dengan dipasangnya alat penangkap asap cair ini, dapat mengubah limbah asap menjadi asap cair yang mempunyai nilai tambah menjadi produk baru yang dapat dipasarkan. Pembuatan alat berasal dari bahan stainless steel, agar produk (asap cair) yang dihasilkan berkualitas bagus, yaitu aroma menyengat dan warna lebih pekat. Stainless juga meningkatkan 20-25\% jumlah asap yang dihasilkan dibanding menggunakan alumunium. 


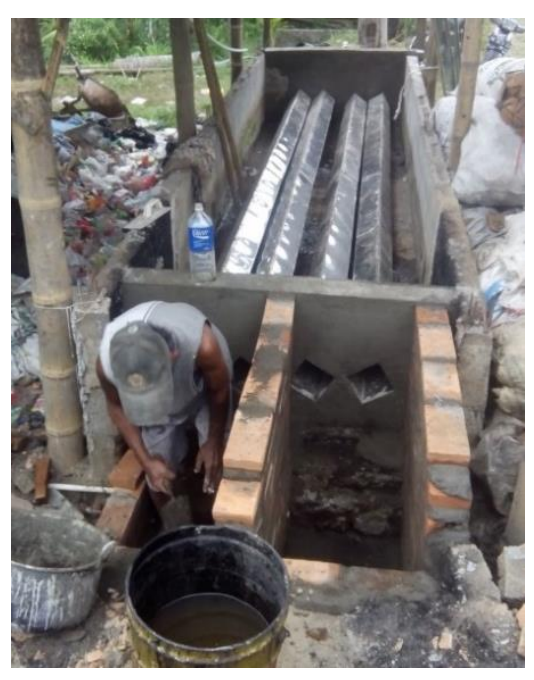

a

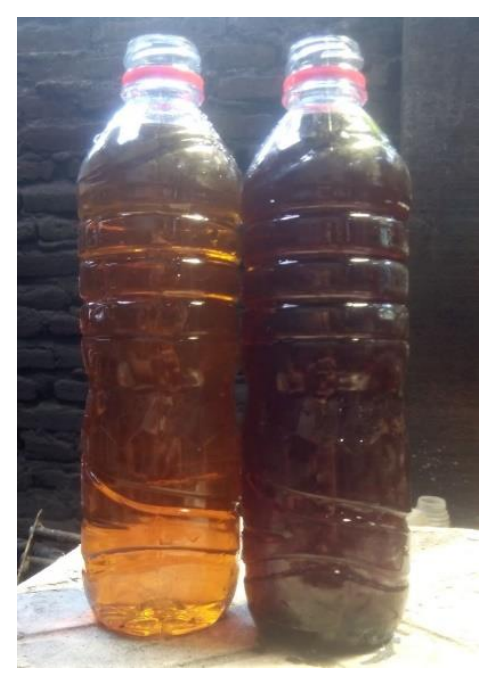

$\mathrm{b}$

Gambar 7. a) Pemasangan alat penangkap asap cair, b) Perbandingan asap sebelum dan sesudah dipasang alat

Gambar $7 \mathrm{~b}$ tersebut adalah perbandingan hasil asap cair dengan menggunakan bahan stainles dengan aluminium. Gambar asap sebelah kiri adalah yang dihasilkan menggunakan alumunium. Warna lebih terang karena tercampur dengan air, diakibatkan alat yang bocor dan bau kurang menyengat.

4. Pelatihan manajemen keuangan memberi pemahaman manajemen pembukuan yang baik agar mitra mampu mengelola keuangan usahanya dengan baik. Dapat memisahkan dengan keuangan pribadi. Adapun tahapan untuk dapat melakukan pembukuan adalah dengan menyusun jurnal, pemindahan jurnal ke buku besar, membuat neraca saldo, serta pembuatan laporan laba rugi, laporan perubahan modal, dan neraca. Berikut gambar 8 adalah proses pendampingan terhadap mitra:

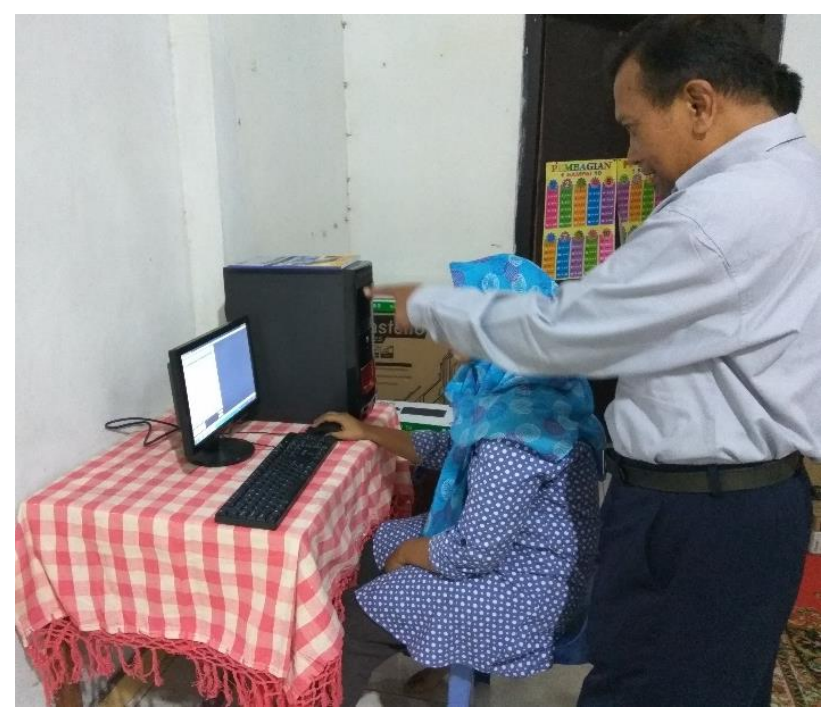

Gambar 8. Kegiatan Pendampingan Keuangan 


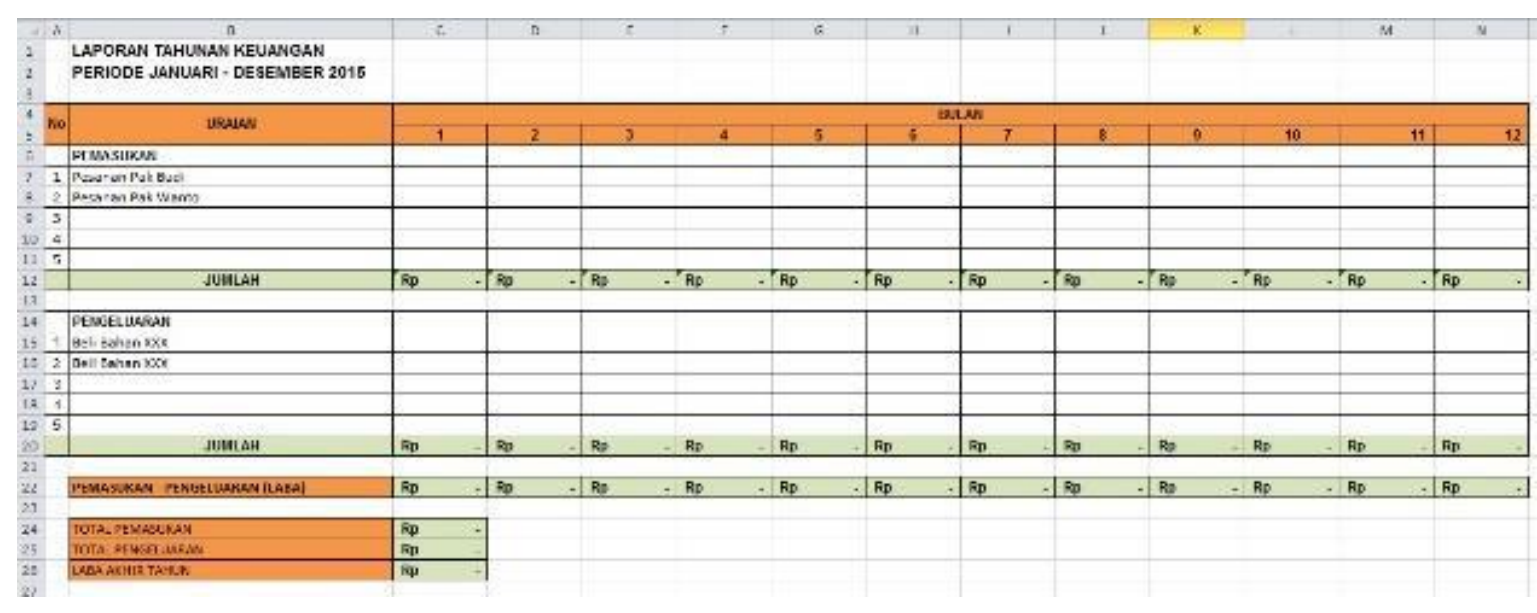

Gambar 9. Template Laporan Keuangan

\section{KESIMPULAN}

1. Dari kegiatan ini, mitra mempunyai media pemasaran yang lebih luas dan dapat mengelola websitenya secara mandiri. Sehingga masyarakat mendapat informasi mengenai produk yang dihasilkan melalui katalog dan dapat memberi edukasi kepada masyarakat terhadap manfaat dan penggunaan produk melalui artikel yang di publish pada websitenya.

2. Dengan adanya alat penangkap asap cair, dengan mengganti pipa pendingin alumunium dengan ketebalan $0,3 \mathrm{~mm}$ panjang 24 meter menjadi stainless steel ketebalan $1.5 \mathrm{~mm}$ panjang $24 \mathrm{~m}$, maka mitra mempunyai satu produk tambahan yang mempunyai nilai jual, yaitu asap cair. Serta kualitasnya meningkat, karena asap cair yang dihasilkan tidak tercampur dengan air.

3. Manajemen keuangan sangat diperlukan oleh mitra, karena dapat memisahkan keuangan pribadi dengan keuangan usaha. Sehingga mitra dapat mengetahui posisi keuangan usahanya, laba atau rugi. Serta dapat menggambil keputusan terhadap posisi keuangannya, seperti penambahan aset, pengembangan usaha, dan lain-lain.

\section{UCAPAN TERIMA KASIH}

Dengan terlaksananya kegiatan pengabdian ini, diucapkan terimakasih kepada kementrian Ristek Dikti yang telah mendanai pengabdian kepada masyarakat melalui program IbM tahun 2016 2017. Serta Departemen Pengabdian Masyarakat Universitas AMIKOM Yogyakarta yang telah menfasilitasi terlaksananya pengabdian masyarakat.

\section{DAFTAR PUSTAKA}

Jogiyanto, HM. Analisis dan Desain Sistem Informasi: Pendekatan Terstuktur Teori Dan Praktek Aplikasi Bisnis.

Dwi Prasetyo, Didik. 2003. Tip dan Trik Kolaborasi PHP \& MySQL untuk Membuat Web Database yang Interaktif. Jakarta: Penerbit PT Elex Media Komputindo.

Triyanto Widodo, Hg. Suseno dan Firma Sulistiyowati, Dionysius Desembriarto. 2005. Reposisi usaha mikro, kecil, dan menengah dalam perekonomian nasional. Penerbit Universitas Sanata Dharma.

Mardiyanto, Handono. Inti Sari Manajemen Keuangan. Penerbit PT. Gramedia Widiasarana Indonesia. 